\title{
Kierkegaard on Abraham's Tragedy: the Loss of Community
}

\author{
ELSEBEt Jegstrup
}

\section{The Problem}

Much has been written about Abraham's story, including Kierkegaard's several versions of it. The "teleological suspension of the ethical" was the mainstay of much traditional Kierkegaard scholarship on Abraham - the sine qua non for those locating Kierkegaard's writings in evangelizing fundamentalism. With respect to the latter, Kierkegaard's claim that individuality ranked higher than "what is generally the case" (det Almene) ${ }^{1}$ seized readers with fervour. Although such readings of Kierkegaard are unfortunate, it remains difficult to ascertain his intended meaning, chiefly because we must attempt do so from the perspective of one Johannes de silentio, ${ }^{2}$ a so-called "pseudonymous" author whose exclusive task it is to speak. What I would like to do in this paper is to offer a phenomenological account of this particular pseudonymous author's exclusive task, namely to describe what it is entirely impossible to understand, since Abraham's own experience is impossible to fathom because it exceeds language, or at least intelligible language. By contrast, with respect to the experiences and tasks of the followers of Abraham, one S. Kierkegaard will later reveal them as entirely understandable, and hence possible to share. I shall argue that Abraham, in spite of also being a follower, of course, was and always will stand in the light of difference, for his task was other than that of following. His experience can be shared with no one. It is an experience that is inadequately expressed by Johannes de silentio's dramatic description of Abraham's journey 
to Mount Moriah—a description whose energy seeks to un-conceal the "autopsy upon which thinking's terror depends" (Garff 163; my translation), the journey of an absolute believer and hence the unthinkable road of irreducible singularity.

The emphasis of the story as it unfolds in Fear and Trembling, Kierkegaard's most (in)famous text, is the road of the founder, the road of "God's chosen one," "the father of faith" (Kierkegaard, Fear 18; SV5 19). He was the only one, the first one, as Johannes de silentio emphasizes, the founder of a religion. Here I purposely emphasize Abraham in terms of difference. Abraham was the only one, the reader is told: "the god" required more of his faith than was the case for his followers, at least as one S. Kierkegaard, author of Works of Love, understands it. Abraham is not like his followers, neither Jews nor Christians. The latter, of course, are the followers of Christ more than Abraham, but Abraham stands at the beginning for them too, and so they are also his followers even if in a slightly different way. The notion of faith differs between Judaism and Christianity, but not a great deal, according to Kierkegaard.

Abraham's faith in the "sublime" gave birth to a nation, but it was also the source of a sacrifice on his part. ${ }^{3}$ Without being provided with reasons, the chosen one is called upon for absolute obedience-God is wholly other (Derrida 57). Again I differentiate Abraham from his followers. The requirement of absolute obedience of the kind we see in Fear and Trembling is for Abraham and for him alone, something we begin to understand when we recall that he was chosen first, and tested second—Abraham had to accept his election first, before he could travel with Isaac to Mount Moriah. Acceptance and obedience precede the test. The problem is, of course, that this particular acceptance is problematic; after all, Abraham is merely a human being, but a human being selected for a very special task, a task that transcends ordinary human experience. 
Tragedy cuts into such a story deeply inasmuch as a founder, whether of a nation or a religion, ideally understood, cannot have personal interests interfere with his tasks. That is to say, the family and the community in which he dwells must remain an abstraction, separate from his concrete task. In a very tragic sense, therefore, Abraham loses the larger world. As Derrida would argue, "religion in the Abrahamic definition tends to resist true openness toward the other" (Borradori 155). Like Plato's philosopher-rulers, like Rousseau's legislator, these founders could not have a personal stake in their creations - the same is true for Abraham. Although eulogized and most deserving of its benefits (Machiavelli Ch. X), none of these founders could participate in the community. Rather, the founder lives beside, absently present, anonymous, and unrecognizable, perhaps abiding as a "tax collector," as de silentio suggests, but never able to self-disclose, never being able to express the ethical, hence the human. On the one hand, one might say that within his faith Abraham lived authentically. Differentiating himself from his founder, Johannes de silentio characterizes Abraham and his faith in the following terms.

The dialectic of faith is the finest and the most extraordinary of all; it has an elevation of which I can certainly form a conception, but no more than that ... I can walk upside down in existence, but I cannot make the next movement, for the marvellous I cannot do-I can only be amazed at it (Kierkegaard, Fear 36; SV 5, 35).

On the other hand, we have to acknowledge that within his loss Abraham lived entirely inauthentically as an outsider and spectator. He controlled nothing; his relationship to God became the essential matrix of his life (Cahill 84-87). His role demanded silence-therefore the loss. He could live with Sarah (who, however, died fairly soon afterwards), and, of course, with Isaac, but only in pain. He could tell them nothing, and within the community in which he dwelled, he could only observe, not participate. ${ }^{4}$ He could not tell the truth: that he was ready to commit murder. He could not express his ethical task, as noted in "Problema I" of Fear and Trembling where de silentio 
asks with alarming calm, "If Abraham actually had sacrificed Isaac, would he therefore have been less justified?" (Kierkegaard, Fear 63: SV5, 59). Derrida suggests that Abraham was imprisoned in his singularity by his silence. Speaking relieves us, says Johannes de silentio, "for it translates into the general" (Kierkegaard, Fear 113; SV 5, 102). Language interrupts singularity, involves it in the general in all its ethical and political dimensions, muddying its perspective and thereby depriving it of liberty and infinite responsibility. Within the context of the general, the infinite withdraws into the background, and has little if any voice. The scandal is that the silence of Abraham—-the silence of singularity—renders him unaccountable with respect to others, and hence from an ethical perspective, Abraham is absolutely irresponsible—-the aporia of responsibility (Derrida 60). ${ }^{5}$

Some Kierkegaard scholars would reject such an interpretation inasmuch as Abraham gets his son Isaac back, a circumstance that has often been construed to mean that Abraham gets his complete world back. I too came to such a conclusion when first reading Fear and Trembling, but a footnote in the later Concluding Unscientific Postscript brought me to a very different reading. There, Johannes Climacus, another pseudonymous author, suggests that Fear and Trembling constituted a "rash" or "reckless" "anticipation."

In Fear and Trembling, a "knight of faith" such as this was portrayed. But this portrayal was only a rash [or "reckless"] anticipation, and the illusion [or perhaps "disappointment" (Skuffelse)] was gained by depicting him in a state of completeness (hence in a false medium) instead of in the existence-medium, and the beginning was made by ignoring the contradiction-how an observer [de silentio] could become at all aware (opmerksom) of him [Abraham] in such a way that he could place himself, admiringly outside, and admire that there is nothing, nothing whatever, to notice (morke), unless Johannes de silentio would say that the knight of faith is his own poetic production (Kierkegaard, Postscript 500; SV10 178).

According to this, neither Johannes de silentio nor any reader can claim anything substantial about the Abraham of Fear and Trembling, who remains beyond all comment—again a point of radical differentiation. Climacus understands what de silentio presents as abstraction, utterly unrealistic, 
false, and hence not at all as faith concretely presented. Climacus has a rationalist's view of things, and although he does not say so directly, he finds the whole idea of the teleological suspension of the ethical entirely implausible because the ethical is a vital part of the "existence-medium."

One needs to come to Works of Love, reading it after Fear and Trembling first, and the Postscript second, and one needs to pay close attention to the journal note that explains in a few well chosen words that everyone has misread Kierkegaard's early authorship, and that it merely attempts to expose all the possibilities of personhood uninhibited by the kind of background Heidegger would call being-in-the-world. The later authorship (re)installs the background as the essential community of all relationships, limitations and responsibilities—resembling Heidegger's understanding of Dasein being-in and hence 'always already in the world.' Poking fun at Descartes, the journal note concludes, "continually when I have first presented one aspect clearly and distinctly, then the other affirms itself even more strongly" (Kierkegaard, Journals \#5972). Thus there is good reason to read Works of Love - the true "existence-medium"—as the parallel or companion to Fear and Trembling, which is intended for the ordinary believer, the ordinary human being who is not a founder, but only, at best, a follower, at least from one S. Kierkegaard's perspective—another pseudonym perhaps.

\section{The Loss}

All of this to allow the reader to understand what I mean by Abraham's tragic loss. But does he lose anything? Yes he does. It is not accidental that the chapter in Fear and Trembling titled "Problema I" begins with these words which articulate the problem:

The ethical as such is what is the general condition [det Almene], and as to what is the general condition it applies to everyone, which from another angle means that it applies at every moment [ethvert Øjeblik]. It rests immanent in itself, has nothing outside itself that is

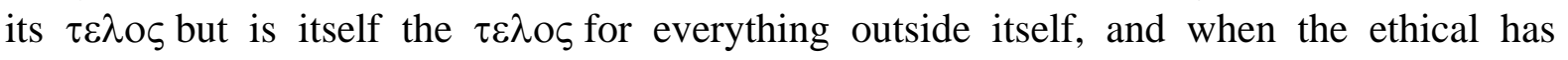


absorbed this into itself, it goes no further. Immanently sensate and psychically qualified singularity [den Enkelte] is that singularity who has his $\tau \varepsilon \lambda \mathrm{o} \varsigma$ in what is the general condition, and this is his ethical task, continuously to express himself in this, suspend [ophœve $]^{6}$ his singularity to remain in what is the general condition (Kierkegaard, Fear 54; SV 5, 51; emphasis added).

The significance of this beginning of the main part of Fear and Trembling, "Problema I," has often been read as a negative preface to real faith, as that which stands in the way of faith, and hence as detrimental to even the possibility of the leap that faith implies. In other words, the ethical is seen as an arbitrary hindrance to religion, to the acceptance of God's grace. But what happens if we read this beginning as a positive moment. Then suddenly we begin to understand in a deeper sense why it is necessary to differentiate between Abraham and his followers, why the founder, in spite of his humanness, must live in a different way, away from all others, for he is doing God's work on Earth. He is founding a religion and bringing it to the people. In other words, he is bringing that by which the ethical must ultimately be grounded to counteract the arbitrariness of an ethic based on social convention. In Works of Love we shall see how this is worked out. Here, in Fear and Trembling, we notice that the transformation that Abraham must undergo in order to overcome his natural self, to accept that his self-interest must coincide with the interest of the people-much like Plato's potential philosopher-ruler (Plato, Republic 347d)—necessarily entails the loss a human being must feel when separated from his community, from his family, from what he loves. Abraham was a human being chosen to do something almost superhuman-therefore the loss. The beginning of Fear and Trembling thus clearly states what Abraham has lost—"what occupied him was not the beautiful tapestry of imagination but the shudder of the idea" (Kierkegaard, Fear 9: SV 5, 13)_but his singularity was called to dominate as he, in his response to God's command, took himself out of the ethical task that belongs to the rest of us. 
To understand Abraham's loss better, one can go in two directions. One can go to the essay in Either-Or, Vol. I., ${ }^{7}$ with the awkward title "The Ancient Tragic Motif as Reflected in the Modern," a work that preceded Fear and Trembling. Another direction to pursue to understand the meaning of the loss Abraham suffered is Works of Love wherein we shall see how the followers practice their faith. But, in the "The Tragic Motif," Kierkegaard, in his usual concealment of direct communication by means of indirect communication, first turns to Aristotle who teaches that we are political or social beings and thus we have a fundamental need for community, a need expressed in action as thinking and character ( $\delta \imath \alpha v o \imath \alpha \kappa \alpha \iota \eta \theta o \varsigma)$. "Being political," we learn, means that singularity is constituted by a constant dialogue between the individual and the background. In ancient tragedy, the role of the chorus is precisely to announce that background in order to speak for what Kierkegaard refers to as "the more [det Mere], the community that will not merge into the individuality" (Kierkegaard, Either 143; SV2, 133). With pure subjectivity, in contrast, there is no dialogue, the many voices have been stilled. Where there is no background, there can be no discourse. The other is no longer differentiated; the other recedes into herself, meaning there is a forgetting of an existential (sense of) belongingness. This is Abraham's loss. In his Journals Kierkegaard makes the following notation, again differentiating Abraham:

While the intellectual tragic hero becomes immortal before he dies, the [ordinary?] tragic hero, for whom the meaning of life (Livs-Betydning) lies in his deed or action (Handling) that belongs to the external world, becomes immortal after his death ... Abraham's distress lies in the silence (Kierkegaard, Papirer IV B 93, 2, 3).

In a much later Journal notation from 1851 and hence written after Works of Love, Kierkegaard continues:

Abraham offered the lamb and went home with Isaac whom he kept. But, said Abraham to himself, with this story I have forever been made heterogeneous with what it means to be a human being [med det at vore Menneske]. Oh Lord, if it would have pleased you to let me, 
though I became a human being, to have become in the shape of a horse, I would not be more heterogeneous from being a human being than I have become with this event; not that it is such a big difference to not have the same shape in common as is the difference not to have the same ideas, but to have them totally opposite on the most crucial points (Kierkegaard, Papirer X 4 A 357).

For S. Kierkegaard, at least, it is quite clear that Abraham now seems to be anything but human. He is unable to express all the requirements of human experience in the world, including the Christian requirement that he love his neighbour as himself, a kind of love that in S. Kierkegaard's interpretation, as we shall see a little later, comes to look quite different from any Christian understanding of this concept. But there can be no doubt that in Kierkegaard's understanding of the "existence-medium," the other is always already there requiring your attention-therefore Abraham's tragic but necessary loss.

In the essay "The Tragic Motif," a phenomenology of isolated and disintegrated modern singularity is presented in comparison with the belonging individual of the ancient Greek city-state following Sophocles' Antigone. It reads much like the description of Abraham's story after his act of "absolute responsibility," a kind of responsibility Derrida considers essentially inconceivable, unthinkable, because it "needs to be exceptional or extraordinary" (Derrida 61). Tragedy itself, Kierkegaard argues, gives voice to the question of being in the world. Its task is to make human beings recall that they are not isolated beings targeted by conniving gods (Snell 20), but beings capable of freely creating their own future, good or bad, within a given horizon that posits possibility, a circumscribed possibility for sure, but a possibility nevertheless. Tragedy was (and is) a reminder that "even if the individual [Individ] moved freely, he nevertheless rested in substantial determinants [Bestemmelser], in the state, the family, in fate" (Kierkegaard, Either 143; SV2, 133). The ancient Greek individual was understood and understood himself as a belonging creature 
connected to both finite and infinite backgrounds and not without tension. In such a society, the individual had a responsibility to the something "more" (det Mere) outside itself, the kind of responsibility understood in a general sense as the ethical, and hence not the kind of responsibility to which Abraham had committed himself when he began his journey up Mount Moriah. Abraham's responsibility "must therefore be [ethically] irresponsible in order to be absolutely responsible" to the god, as Derrida interprets (Derrida 61).

Considering the historical period of Abraham, and the absolute dependency of the individual on the way of the community as a whole in such days, when societies could all but disappear (by plague or warfare), the comparison I will make here will be appropriate, but possibly not stark enough. While Derrida speaks of "sacrifice," I prefer to think of such absolute responsibility as "loss" because Abraham was ethically responsible up until he was tested, or he presumably would not have been chosen. He had been given the task of founder before he was so severely tested, and thus the loss seems imposed and not really chosen, although there is room for disagreement on this point. In other words, I read it as a circumstance of before and after, not as an either-or proposition. His loss certainly suggests that "solitary reflection"-here understood as Abraham's absolute faith, a faith without doubt—was unable to communicate existence proper to Eksistents. Eksistents is Kierkegaard's term for being-in-the-world, and without such a proper 'way of life,' the person is unable to share moral experience, unable to relate to a background that speaks for the whole, unable to engage in dialogue so important for the idea of community as such.

So what is it like, this modern experience of singularity in general? Here I shall rely to some degree on the essay "The Tragic Motif" as well as on Two Ages in order to reveal the loss suffered by modern singularity and even more so by Abraham, in other words, the tragedy he suffers, if one 
can even call it that. In the essay "The Tragic Motif," Sophocles' Antigone is a primary example of the ambiguity of responsibility that confronts the human project, and Antigone herself is a primary example of the risky business of decision that is constitutive of tragedy. Her pain was to come up against the condition of undecidability, a condition that nevertheless requires decision. As such tragedy gives voice to the question of being-in-the-world. Its task is to make the members of a given society understand themselves as belonging beings with responsibilities beyond themselves to the larger whole. One might say, this idea of belongingness forms the paradigm for any culture or paideia that such a society would enjoy.

There is the rub. Kierkegaard is not interested in ancient Greek tragedy per say, but with how the tragic, the "truly tragic" (sande tragiske) (Kierkegaard, Either 140; SV2, 130) expresses itself in modernity, and with its didactic lessons. Although the context of the modern age is obviously much different from that of ancient Greece, human nature has not changed, and therefore the relevance of tragedy must be teleologically conceived (Kierkegaard, Either 140; SV2, 130). Modernity is in need of a corrective, we learn, and therefore, as Sylviane Agacinski has noted, the negativity of an ironic communication must be timely (Agacinski, Apartè 13). What needs to be corrected? What is the problematic here? Modern individual experience suffers from the loss of a sense of belonging, a loss of community; modern "existence [Tilvaerelse] is undermined by the subject's doubt, and isolation continually gains the upper hand more and more" (Kierkegaard, Either 141; SV2, 131). The communication on tragedy must address this problematic, but not directly. A narrative is required. Sophocles' tragedy provides both the narrative and the corrective.

In modernity, the two-dimensional context of the Greek polis has been negated and substituted with a depersonalized and disembodied subjectivity, which is oblivious to context, 
replaces the play of ambiguity with scepticism, and is utterly apolitical (Kierkegaard, Either 141; SV2, 131). There has been a forgetting of the tension of existence. Why is this a problem? According to the author, this pathogen of forgetting implies self-denial of something essential to Existents. Although Kierkegaard's meaning becomes its own opposite in the case of Abraham, in view of earlier remarks the other part of existence, what Kierkegaard referred to as the "existencemedium," is very much lacking in Abraham's life. This is the medium best delineated in Works of Love. Although for Abraham we are talking about a loss, in "the present age" there has been a forgetting of background, what is referred to as "the more" (et Mere) in "The Tragic Motif," and consequently there has been a forgetting of the responsibility that in times past held communities together, a forgetting of the transcendental that maintained the invisible, the hidden from where responsibility flows. Instead we are confronted with the tragic and comic circumstances of pure subjectivity manifesting its accidentality over against totality (Kierkegaard, Either 142; SV2, 132). If we were to apply this to Abraham's story, it would seem more like a choice of the divine over the human, as some would say, but perhaps it would make sense to call it the loss shouldered by Abraham because of his role as founder. The Christian church also chose to deny its clerics a fundamental part of the "existence-medium," unlike Plato for whom the sensual could not be denied.

But the narrative continues. Under the circumspect conditions of this narrative, the concept of obligation has been bracketed. As Kierkegaard argues, "Our age is sufficiently depressed to know that there is something which is called responsibility and that this means something. Therefore, although everyone wants to rule, no one wants to have responsibility" (Kierkegaard, Either 142; SV2, 132). That is to say, the responsibility that held the polis together has dissolved in both directions. Arendt would argue that the household realm has dramatically enlarged into what today 
we call society (Arendt, Human 22-28), making any political action aim at more or less private affairs rather than solving what ought to be strictly political or public problems, that is, problems citizens share. The notion of responsibility now sows tension in human experience rather than relationship. Now the dialogue is strictly internal, which certainly is true for Abraham; now subjectivity controls both positions and easily erases the nagging tension. Now freedom is not to choose within a set of given circumstances; now freedom is to do (frivolously): "I think, therefore I am," and therefore I can do-as I like. This latter dimension of modern existence, of which Kierkegaard speaks so scathingly, cannot be applied to Abraham. This was not part of a modus operantum known to him. But in this present age there are no gestures or gifts without expectation, no sense of obligation without reciprocity. The concept of the "other" is buried in the depth of the soul. Reason knows, but knowing and experience have been sharply differentiated in modernitythis is the stuff of guilt and anxiety. Egoism wins the battle, the "other" is forgotten-it is only absently present. The other in terms of the community is also absently present for Abraham but not forgotten. That is precisely the loss. Thus we can say that Abraham's life, after the event, has a "truly tragic" dimension inasmuch as there is a denial of his true nature as a belonging being.

For S. Kierkegaard, at least, it is quite clear that Abraham now seems to be anything but human. His silence could not translate into the external world, his silence had to remain within him always. He is unable to share his experience with his fellow beings who constitute the alienated background. He is unable to express all the requirements of human experience in the world including the Christian requirement that he love his neighbour as himself. But there can be no doubt that in Kierkegaard's understanding of the "existence-medium," the other is always already there requiring your attention—-this is Abraham's tragic but necessary loss. 


\section{Modern Subjectivity and Abraham}

We can also turn to Two Ages and Works of Love, both of which were part of the later authorship and thus post-date both Fear and Trembling and the Postscript footnote referred to above. Two Ages: A Literary Review starts out as a critique of certain literary attempts by a friend of Kierkegaard, Mrs. Gyllembourg, and turns into a very accurate description of modern atomized individualism, a serious degeneration, according to one S. Kierkegaard. Not all of this applies to Abraham, of course, but Kierkegaard makes certain points that enable us to understand the external nature of Abraham's relationship to his community. Thus Kierkegaard identifies the problem of modernity as a complete loss of traditional community "of the sort that provided their members with a sense of identity, and the concomitant rise of the autonomous individual whose social relationships are regarded as contingent and alterable without affecting his identity" (Rudd 132). In modernity people have become spectators with respect to existence; they are overwhelmed by inertia. A general inability to translate the considerations of reflection and observation into deed pervades individual experience. Insofar as the ethical only expresses itself in terms of action or decision, and not without moments of undecidability in a general sense, this all important category of Existents was negated and, by necessity, was denied Abraham as well. Here there is no sense of singularity in the Levinasian sense. The other as other remains obscure, and this is essentially true for Abraham as well.

Kierkegaard continues in Two Ages with some comments about either being in contradiction with oneself or being in harmony with oneself, and these apply nicely if not absolutely to our thesis about Abraham. In terms of the principle of contradiction Kierkegaard insists that it constitutes an 
axiom of existence. "To suspend (hreve) the principle of contradiction is the existential expression for being in contradiction with oneself" (Kierkegaard, Ages 97; SV14, 88; translation amended). And to be in contradiction with oneself is to be separated from the conceptual framework that forms the essential distinction between good and evil in action and decision (Kierkegaard, Ages 66; SV14, 61). To suspend this essential distinction is to be nothing at all. To put it in positive terms, it means that to be existentially, and hence to acknowledge the distinction, is to be in harmony with oneself, with whom one is. It is to be at home with oneself. But what exactly did Kierkegaard mean by being at home with the self?

The principle of contradiction strengthens the individual [Individ] in faithfulness to itself, so that he, like that steadfast number three Socrates speaks of so beautifully, will rather endure everything than become a number four or even become a very large even number. He will rather be something small in faithfulness to himself than all sorts of things in contradiction with himself (Kierkegaard, Ages 97; SV14, 89).

I want to question whether Abraham was ever in harmony with himself after the event on Mount Moriah? Does he not suffer a sense of unheimlichkeit, to use Heidegger's terms? When S. Kierkegaard speaks of being in harmony with oneself, he of course is referring to Plato's Phaedo (104c), but more importantly, he is also referring to the Gorgias (482c) where Socrates says to Callicles, in Hannah Arendt's rendition:

It would be better for me that my lyre or a chorus I directed should be out of tune and loud with discourse, and that multitudes of men should disagree with me rather than that I, being one, should be out of harmony with myself and contradict me (Arendt, Life 181).

Arendt maintains the emphasis on "being one," claiming that it is frequently left out in translation. What is of particular interest in regard to this quotation is its relationship in the dialogue to philosophy's capacity to engender community as opposed to the efforts of rhetoric. As Socrates insists, "philosophy speaks always the same" (482b) while rhetoric, the language of the Sophists, 
caters to people's divergent interests, not to their needs, which are always the same. Thus Plato performs a double move inasmuch as Socrates' love of philosophy not only creates harmony in his soul but also in the city. As Arendt concludes elsewhere, this positive assertion of philosophical truth, which has an undeniable impact on practical conduct, is not entirely apolitical (Arendt, "Truth" 247-48). For Kierkegaard, to always speak the same is to acknowledge the principle of contradiction with respect to its broadest implication. It means to be in character with oneself and to remain so, and hence to be faithful to oneself, that is, to act in accordance with one's daimon, what kept

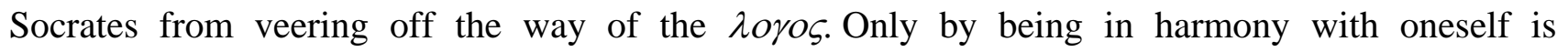
community possible. Can we then say that Abraham was in contradiction with himself inasmuch as his being in the "existence-medium," being in the community, could not be ethically expressed, could not be morally manifested?

To exist without responsibility generally speaking is for Kierkegaard to be superficial, and superficiality suspends the distinction between concealment and disclosedness. Inasmuch as "superficiality gives the appearance of being anything and everything," what is essential may not be thought through in concealment, and thoughtful intention is prevented from emerging. Everything is hurriedly forced to the surface, undeliberated, and what is disclosed is characterized by emptiness. It is an emptiness which, Kierkegaard says, "nevertheless extensively wins the disappointing advantage of delusion over essential disclosedness which has the homogeneous essentiality of deepening" (Kierkegaard, Ages 102; SV14, 93). Rather than achieving transparency, this form of disclosedness only uncovers appearances. That is to say, psychologically, the single self is not tending to personal development in terms of its nature as spirit. Here we run into a paradox, and perhaps we are carrying this analogy of modern experience too far, for here we cannot say that Abraham is not attending to 
himself as spirit. But there is a sense in which he conceals his spiritedness- he may be the tax collector, we do not know. Thus not to be faithful to oneself or not to be in harmony with oneself expresses itself in a number of debilitating ways that are all grounded in the original suspension of the principle of contradiction. Whereas Kierkegaard sees the modern experience being caught up in a sharply differentiated externality, Abraham is caught up in a sharply differentiated inwardness that nevertheless also suspends the necessary principle of contradiction. To put it in less formal terms, Abraham is unable to master the dialectic; he is in disharmony with himself precisely because his dialectic has lost its other dimension. His absolute responsibility indeed causes him to be completely irresponsible toward the ethical, and thus entirely irresponsible to himself as a human being. Abraham has been isolated, not from the worldly, but precisely into the religious where we cannot follow him and where we cannot understand him. He cannot share his experience with the community, but neither can he make the leap into the religious for the community. Abraham made the leap, welcomed "the god," an act the rest of us can only admire. To understand what is involved in such a possibility, the condition for the freedom of possibility of the leap, we must turn to Kierkegaard's Works of Love where to love the other as oneself demonstrates what is involved in such a leap and at the same time demonstrates Abraham's loss in its deepest and most tragic sense.

\section{Kierkegaard's Singularity — the existence-medium}

In Works of Love Kierkegaard puts Abraham's followers into the "existence-medium" in which they properly belong. The question is, can Abraham also be folded in? We shall see. In this "existence-medium" it becomes clear that the fullest kind of life presupposes that we must adhere to what a student of mine prefers to call "eternal love," as Kierkegaard himself now and then refers to 
Christian love, what I have elsewhere called "love as obligation" (Jegstrup, "Text"). One might prefer this terminology because of the worry that the idea of Christianity would prohibit others who happen not to be Christian from taking the path of eternal love. ${ }^{8}$ Eternal love is the path which Abraham's experience on Mount Moriah prohibits him from following. We must ask why? It sounds peculiar inasmuch as his entire life is inwardness. One might have thought that Abraham resembled the tragic hero that Johannes de silentio characterizes in Fear and Trembling, that he indeed engaged in eternal love. However, the tragic hero has his $\tau \varepsilon \lambda o \varsigma$ within the ethical-inasmuch as his moral virtue is evaluated in terms of the social he is considered great. Abraham has his $\tau \varepsilon \lambda$ o outside the ethical and is considered great because of a purely existential virtue that lacks all transparency, much like the modern individual who, subsumed by guilt, also lacks transparency. Thus in modern drama there is no chorus to express the ethical, no chorus to cry for the hero's tragic mistake. The stage of Kierkegaard's modern Antigone is interiority, not to be confused with inwardness. It is private, concealed. Her pain renders her isolated, and she becomes as homeless as Sophocles' Antigone who also was "never at home with the living nor with the dead" (Kierkegaard, Either 159; SV2, 147). Her pain is in both cases her outward denial of "the more" that cannot be denied, her denial of externality. She is overcome by guilt and lacks all transparency as she decides to live and die with her secret as does Abraham, and that is "truly tragic." One could argue that S. Kierkegaard's concept of singularity proper as expressed in Works of Love will seem to have the characteristics of the tragic hero yet rely on a particular kind of inwardness that will be manifested in a very different way than is the case for Kierkegaard's Antigone and Abraham.

It is not well known that Kierkegaard dabbled in what Arendt would call "the political." In Works of Love he not only restored the human condition, he also explored that context in all its 
dimensions, including "the political" (Jegstrup "Justice"). In other words, the idea of singularity Kierkegaard developed in Works of Love could easily be called Kierkegaard's "political being." It is this prototype he refers to in the Danish as den Enkelte. But den Enkelte, or singularity, in this case implies a responsibility that has particular characteristics that are developed from Matthew's dictum: "You shall love your neighbour as yourself" (Matthew 22:39). Kierkegaard rewrites this dictum to read: "You shall love the neighbour as yourself." He quickly identifies the neighbour as the other (den Anden), as the next person you see, as all humankind (Kierkegaard, Love 19; SV12, 25). The aim is community and that is singularity's "existence-medium." That, necessarily, is a political concept as Aristotle would insist. Interestingly, Kierkegaard understands this human condition much like Aristotle for whom "he who is without a city is either a god or a beast" (Aristotle 1253a3). The argument is that community is possible for us because we have reason and language, two characteristics enabling a determination of advantage and disadvantage. Without community we are not fully human. In Works of Love, we get the same message from Kierkegaard. Ontologically, he argues, we are belonging beings:

In the busy, teeming crowd, which as companionship is both too much and too little, a person grows weary of society; but the cure is not to make the discovery that God's thought was wrong - no, the cure is simply to learn all over again that first thought, to be conscious of longing for community . . . So deeply is this need rooted in human nature, and so essentially does it belong to being human (Kierkegaard, Love 154-55; SV12, 150; translation amended).

This is precisely where S. Kierkegaard begins his argument by obligating us to love the other as we love ourselves.

Now, there are many versions and interpretations of Matthew's dictum. In the Bible we do not seem to get an interpretation, at least not an immediate one, wherefore all have taken the liberty to form their own readings of this second commandment. The Jews took a negative attitude to the 
golden rule, according to Karen Armstrong, who tells the story of Hillel who, standing on one leg, was challenged to "recite the whole of Jewish teaching: ... 'Do not do unto others as you would not have done unto you"' (Armstrong 235). Although not much of a contrast, John Locke has a more positive view of this command, since he understands freedom to be limited by the law of nature or reason and by the reciprocity of equality. He utilizes "the judicious Hooker" to interpret Matthew: "[M]en [in the state of nature] know that it is no less their duty, to love others than themselves." It is a perfectly rational argument that is frivolously sacrificed on the altar of self-interest when civil or economic society is formed (Locke $\S \S 5,124)$. Thus Locke is really interpreting Matthew to say: Do unto others as you wish they would do unto you, believing that the competitive development of civil society is thus best protected. In other words, the golden rule is utterly dependent upon others believing the dictum in the same way, believing in reciprocity to maintain their rights, and that assumption is more or less what our society has lived by from its very beginning. The golden rule understands Matthew's principle with qualifications.

S. Kierkegaard understands Matthew's Biblical command in a rather postmodern sense, and he reveals this surprising interpretation in a thorough examination of love as such. In The New Kierkegaard I argue:

It is in the how love is expressed, it is in how singularity comports itself that the gifts of love may become visible, not to sense perception but to the mind's eye, not as cognition but as

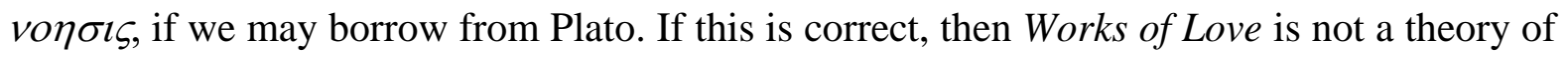
love or even a theory of the works of love, and that would mean it is not an ethic. It is, rather, a deconstructive phenomenology of singularity's being-in-the-world as love, a love that has a vertical direction but whose horizontal connection to existence, we are told, is unfathomable [uudgrundelig] (Jegstrup, New 81; emphasis added).

Kierkegaard addresses the question of love by contrasting eternal love and poetic love. The latter lacks stability, it lacks constancy, it lacks an all-encompassing capacity. It is uncontrollable and 
unreliable and needs constant testing, and it can turn into something else, into hate or jealousy. But its worst characteristic, from Kierkegaard's perspective in Works of Love, is that it is preferential and thus exclusive. It can only love one person "above all others"—at a time! Eternal love, in contrast, "loves the whole human race, all people, even the enemy" (Kierkegaard, Love 19; SV12, 25), and hence is all inclusive. One could say it presupposes community. It is a kind of love we have control over; it constitutes comportment; it is the way singularity meets the world; it is something of which we can take charge, while falling in love is an event that happens to us. Eternal love has constancy, is entirely reliable, and it purposely reaches out. "Only when it is a duty to love, only then is love eternally secured against every change, eternally made free in blessed independence, eternally and happily secured against despair" (Kierkegaard, Love 29; SV12, 34).

The how of its love is to presuppose love in the other, and to presuppose love in the other is to build up the self. "This 'up' in 'build up' indicates height, but it indicates height inversely as depth" (Kierkegaard, Love 211; SV12, 204-05), ranking life qualitatively inasmuch as it is singularity that is built up by presupposing love in the other. Importantly for S. Kierkegaard's understanding of eternal love, it is not about transforming the other; rather it is about letting the other be, thereby transforming oneself (Kierkegaard, Love 21, 217; SV12, 27, 210). Poetic love makes demands of the other, attempts to change the other, something the self would not like, whereas eternal love makes no demands, does not try to change the other, does not try to reduce the other to the same (Kierkegaard, Love 21; SV12, 27). Eternal love lets the other be. To love the other as the self is therefore to love the other in the way the self would wish to be loved. To love the other is to let the other be. ${ }^{9}$

Love as obligation is structural; it is directed both vertically as well as horizontally. The religious is the responsibility of the subject to the wholly other (tout autre)—a general structure of 
experience-an obligation without ethics, as Caputo interprets Abraham's act on Mount Moriah (Caputo 206). This is also how every other subject loves. The only difference is that this general structure of experience expresses itself horizontally, not in terms of Abraham's loss, but in terms of relating to every other. The gift of love is not to see difference, but to experience equality through difference, to close one's eyes and just love — that is to say, to love the other regardless of difference, regardless of disagreement, regardless of circumstances (Kierkegaard, Love 118; SV12, 118). Thus love is a gift that needs to be given. Derrida often asked whether there was such a thing as a gift since it seemed to be always attached to expectation or reciprocity. I would like to ask whether it is a gift if it is not given? Kierkegaard seems to want to answer in the negative to this question (Kierkegaard, Love 67; SV12, 70). Love, to be love, must express itself. If it is not given, is there love? Kierkegaard reduces poetic love to self-love—something with which I think we all, ultimately, must agree. Eternal love is also grounded in the self, as we have seen, but expresses itself necessarily to an other. Thus eternal love must operate with closed eyes. The gift of love is the kind of love that "wants the dissimilarity to hang loosely on singularity, as loosely as the cape the king casts off in order to show who he is ... When the dissimilarity hangs loosely in this way, then in singularity there continually glimmers that essential other, which is common to all" (Kierkegaard, Love 88; SV12, 90). The other is always already before singularity, and singularity's responsibility grows out of that condition. But why should he love that other? This is where the persona of Abraham that was drawn by Johannes de silentio in Fear and Trembling truly stands out as a "reckless anticipation," for here in Works of Love, here where singularity is properly located in the "existence-medium," here we come to understand what it really means to love God. 
We are still talking about an act of faith and hence about a leap that looms as virtually impossible from any perspective. In both cases we are talking about absolute obedience, however, the content of the obedience differs. In the case of Abraham, the command from on high deprives Abraham of the dialectic of existence proper, whereas in the case of Works of Love and S. Kierkegaard's reading of Matthew's dictum, the act of obedience maintains and is directed toward human experience in its truest sense-it maintains the relational dimension that according to S. Kierkegaard is ontologically given, making singularity a belonging being and hence responsible to the other. Here the meaning of faith is essentially this: "in love for the neighbor, God is the middle term. Love God above all else; then you also love the neighbor and in the neighbor every human being. Only by loving God above all else can one love the neighbor in the other human being" (Kierkegard, Love 58; SV12, 62). "Christian love is sheer action" (Kierkegard, Love 99; SV12, 100), he argues, sounding a little like Levinas speaking of "performativity." To love in this way is not a cognitive act, but rather it is about doing, about a way of being in the world-for the other (Kierkegaard, Love 223; SV12, 216). This is different from the absolute obedience required of Abraham and which takes him away from the world. But S. Kierkegaard, like Johannes de silentio, is still talking about absolute obedience, except that now the requirement entails something different; now it is about singularity's ethical task for life (Kierkegaard, Love 118; SV12, 117)—and there are no rewards, the reader is warned, in this argument against utilitarianism. Acquiring such clarity of oneself, of the freedom of possibility of singularity as such, these are singular moments of identity that Kierkegaard also speaks of in Philosophical Fragments and most especially in The Concept of Anxiety, where there is a return of the self to the self for an instant, where transparency emerges about the self and the other, and where the soul, as Socrates would say, is in harmony with itself. It is 
true that there are many more moments of loss in between these moments of clarity, but there is also some understanding of the requirements of faith for us all. In Fear and Trembling Abraham loved God at the expense of all others, at the expense of his community. This is certainly a reckless kind of love, for it ignores the world in favour of God, and hence we must ask, why would God create the world if ignoring it was the intent. In contrast, in Works of Love, S. Kierkegaard makes it very clear what it means to love God:

[T] he [eternal] love commandment commands loving God above all else, and then loving the neighbor. In erotic love and friendship, preferential love is the middle term; in love for the neighbor God is the middle term (Kierkegaard, Love 57-8; SV12, 62).

If to love God means to love the neighbour, love the community, then it seems reasonable to ask "Who is this Abraham" that Johannes de silentio vividly describes in Fear and Trembling, for he was cut off from loving his neighbour, cut off from the world, and hence we must ask if he loved God truly, or is it that his task required something the rest of us are not to do, are unable to participate in? As de silentio says with such a deep sense of understanding:

I would not love as Abraham loved, for then I would have held back at the very last minute, without, however, arriving too late at Mount Moriah. Furthermore, by my behavior I would have spoiled the whole story, for if I had gotten Isaac again, I would have been in an awkward position. What was the easiest for Abraham would have been difficult for me-once again to be happy in Isaac!—for he who with all the infinity of his soul ... has made the infinite movement and cannot do more, he keeps Isaac only with pain (Kierkegaard, Fear 35; SV4, 34).

Abraham's loss was tremendous; for his followers, Abraham's love was tremendous, and ultimately we must ask, is this truly Abraham as history imagines, or has it been something entirely different that Kierkegaard is trying to tell us with his manipulation of this Old Testament story? Is the truth not closer to what we learn in Works of Love where the real answer to the question "What does it really mean to love God?" is presented with so much detail, so much historical context, and where 
the responsibility of being a belonging being is so strongly emphasized in a true existence-medium? Is this not closer to the true meaning of faith as love in Kierkegaard's works than what we find in Fear and Trembling? Abraham suffered his loss, we must speculate, precisely because he was the only one, the chosen one, and that was his tragedy, but it is not the tragedy of his followers—at least not in the eyes of one S. Kierkegaard.

\section{Notes}

${ }^{1}$ Old and new translations of Kierkegaard's Fear and Trembling have incorrectly translated "det Almene" to read "universal," but it should be translated as "what is generally the case," "what is generally true," or "the general condition." Nowhere in Fear and Trembling does Kierkegaard use a term that could be translated as "universal."

${ }^{2}$ I write the latter two parts of Fear and Trembling's pseudonymous author's name both without capitalization and in italics inasmuch as that is how it appears in the original (Danish) text.

3 "[A]ll thoughts of the sublime, all eulogies to it, necessarily proceed by reference to some conception of sacrifice, a conception for which the idea of sacrificing a tiny remnant, the little one, will always be possible or conceivable" (Agacinski, "Sublime" 129).

${ }^{4}$ It is interesting to learn in Thomas Cahill's lovely (hi)story of the Jews that Abraham (or Avraham as he is properly called) and his followers set up camp in the desert outside of town, describing themselves as sojourners on the land that God would later deed to his people (65).

${ }^{5}$ For more on Derrida's reading of Kierkegaard see Jegstrup, "Kierkegaard and Deconstruction."

${ }^{6}$ The Danish word ophove includes the ambiguities known from Hegel's use of the German aufheben.

${ }^{7}$ It is unfortunate that the translators of most of the "Kierkegaard's Writings" series have chosen to use a slash between the "either" and the "or" of this title. In Danish it is a long 'dash' which, translated from the Danish, means "thought-line" (tankestreg). Kierkegaard asks the reader to pause before reading on, before choosing!

${ }^{8}$ John Parker MacAllister, "Close Your Eyes." Submitted for presentation at the Appalachian Undergraduate Philosophy Conference, the University of North Carolina at Asheville, October 2006. Some people would of course claim that Abraham was not a Christian but a Jewish prophet. It is an ambiguity that does not seem to bother Kierkegaard. 
${ }^{9}$ In this context I am reminded of Heidegger's concept Gelassenheit which also means to let the other be.

\section{Works Cited}

Agacinski, Sylviane. Apartè: Conceptions and Deaths of Søren Kierkegaard. Trans. Kevin Newmark. Tallahassee: Florida State University Press, 1988.

_ _ . "We are not sublime: Love and Sacrifice, Abraham and ourselves." Kierkegaard: A Critical Reader. Ed. J. Rée and J. Chamberlain. Oxford: Blackwell Publishers, 1998. 129-150.

Arendt, Hannah. The Human Condition. Chicago: The University of Chicago Press, 1958.

—. The Life of the Mind. New York: Harcourt, Brace, Jovanovich, 1978.

__. "Truth and Politics." Between Past and Future. New York: Penguin Books, 1977.

Aristotle. The Politics. Trans. Sinclair and Saunders. London: Penguin Books, 1981.

Armstrong, Karen. The Spiral Staircase. New York: Random House Inc., 2004.

Borradori, Giovanna. Philosophy in a Time of Terror. Chicago: The University of Chicago Press, 2003.

Cahill, Thomas. The Gift of the Jews. New York: Doubleday, 1998.

Caputo, John D. The Prayers and Tears of Jacques Derrida. Bloomington: Indiana University Press, 1997.

Derrida, Jacques. The Gift of Death. Trans. David Wills. Chicago: The University of Chicago Press, 1995.

Garff, Joakim. "The Sleepless": Kierkegaard read aesthetically/biographically. Copenhagen: C.A. Reitzels Forlag, 1995.

Jegstrup, Elsebet. "Kierkegaard and Deconstruction: Is Kierkegaard inter alia anywhere in Derrida's The Gift of Death." Søren Kierkegaard Newsletter no. 41 (February 2001): 19-23.

—. Ed. The New Kierkegaard. Bloomington: Indiana University Press, 2004.

—_. "A Questioning of Justice: Kierkegaard, the Postmodern Critique and Political Theory." Political Theory 23, no. 3 (August 1995): 425-451.

—. "Text and the Performative Act: Kierkegaard's (im/possible) Direct Communications." Philosophy Today 45, no. 2 (Summer 2001).

Kierkegaard, Søren. Concluding Unscientific Postscript, vol. 1. Ed. and Trans. Howard V. and Edna H. Hong. Princeton, NJ: Princeton University Press, 1992. 
—. Either/Or, Vol. I. Trans. Howard V. and Edna H. Hong. Princeton, NJ: Princeton University Press, 1987.

_. Fear and Trembling/Repetition. Trans. and Ed. Howard V. and Edna H. Hong. Princeton, NJ: Princeton University Press, 1983.

_. Søren Kierkegaard's Journals and Papers. Ed. and Trans. Howard V. and Edna H. Hong. Bloomington: Indiana University Press, 1978.

—. Søren Kierkegaards Papirer, 2nd ed. Ed. P.A. Heiberg and V. Kuhr. København: Gyldendal, 1909-78.

—. Two Ages. Ed. and Trans. Howard V. and Edna H. Hong. Princeton, NJ: Princeton University Press, 1978.

—. Works of Love. Trans. Howard V. and Edna H. Hong. New York: Harper Torchbooks, 1964.

Locke, John. Second Treatise of Government. Ed. C.B. Macpherson. Indianapolis: Hackett, 1980.

Machiavelli, Niccolo. The Discourses. Trans. Walker and Richardson. New York: Penguin, 1983.

Plato. The Collected Dialogues. Ed. Edith Hamilton and Huntington Cairns. Princeton, NJ: Princeton University Press, 1989.

Rudd, Anthony. "Reason in Ethics: MacIntyre and Kierkegaard." Kierkegaard After MacIntyre. Ed. John D. Davenport and Anthony Rudd. Chicago: Open Court Publishing Co., 2001.

Snell, Bruno. Discovery of the Mind. Trans. T.G. Rosenmeyer. New York: Dover Publications, Inc., 1982. 